\title{
Preparation and Characterization of Chloride-Free Alumina-Supported Platinum Catalysts
}

\author{
ANTI KOLONIAL PRODJOSANTOSO \\ Department of Chemistry, Yogyakarta State University, Yogyakarta, DIY 55281, Indonesia. \\ ${ }^{*}$ Corresponding author E-mail: prodjosantoso @uny.ac.id \\ http://dx.doi.org/10.13005/ojc/3404046
}

(Received: June 12, 2018; Accepted: July 19, 2018)

\begin{abstract}
Supported precious metal catalysts are extensively used as efficient catalysts. This kind of catalysts, particularly chloride-free catalysts, synthesized using organoplatinum compounds as precursors has attracted immense research interest compared to their parent metals due to their unique physico-chemical properties. The main objective of this research is to prepare and characterize the chloride-free alumina-supported platinum catalysts. An organometallic compound of ammonium bisoxalatoplatinate(II) hydrate was used to prepare unsupported and alumina supported platinum catalysts. A series method including IR, XRD, SEM, TEM, EDA, and XPS was used to characterize samples. The research shows that ammonium bisoxalatoplatinate(II) hydrate could be synthesized and used to prepare unsupported and alumina supported platinum free of chloride impurities.
\end{abstract}

Keywords: Catalysts, Platinum, Chloride-free, XPS.

\section{INTRODUCTION}

Organometallic compounds are widely used as catalyst precursor. ${ }^{1,2}$ A combination of impregnation of the support with a solution containing the appropriate organometallic species and heat treatment can yield metal and/or metal oxide particles uniformly distributed over the surface of the support. Unfortunately since multi-step reaction pathways are frequently involved, the preparation of particular organometallic precursor is often time consuming. A second problem is that chloride containing species are typically the most easy-prepared organometallics. ${ }^{3}$ Thus it is possible that chloride will be present in of the resulting catalysts. ${ }^{4}$ Chloride ions have been reported to be absorbed on, and hence block, the active site of metal catalysts. ${ }^{4-7}$ As such chloride ions can inhibit a number of metal catalyzed reactions. ${ }^{8}$ Removing such chlorides can be both difficult and time consuming since requires additional processing.

Potassium bisoxalatometallate complexes are simple chloride-free compounds. Potassium bisoxalatoplatinate(II) is well known and easy to be prepared. ${ }^{9}$ This complex can be thermally decomposed at relatively low temperatures to the metal and/or metal oxide, and it is ideal precursors 
for the formation of chloride-free catalysts., ${ }^{1,10}$ The high solubility in aqueous solutions suggests it may be straight forward to deposit this compound onto high surface area supports. After heat treated, the metal and/or metal oxide crystallites dispersed over the surface of the support will be obtained.

The presence of $\mathrm{K}$ as a product of heat treatment of potassium bisoxalatoplatinate(II) was confirmed. ${ }^{11,12}$ In general potassium is not believed enhance the catalytic activity of $\mathrm{Pt}$, and there is some evidences that potassium acts as inhibitor. Fortunately the $\mathrm{K}$ species could be removed by washing the heat treated samples with water. However, washing heat treated $\mathrm{K}_{2} \mathrm{Pt}(\mathrm{ox})_{2} \cdot 2 \mathrm{H}_{2} \mathrm{O}$ with water failed to remove all the potassium since in this case the insoluble oxide was formed. ${ }^{13,14}$

The structural studies of $\mathrm{K}_{2} \mathrm{Pt}(\mathrm{ox})_{2} \cdot 2 \mathrm{H}_{2} \mathrm{O}$ demonstrate the presence of discrete $\mathrm{Pt}(\mathrm{ox})_{2}{ }^{2-}$ and therefore it should be possible to replace potassium with ammonium cation. ${ }^{15,16}$ The advantages should be realized by avoiding the use of $\mathrm{K}$. Since the ammonium cation will be oxidized during heat treatment, subsequent washing of the Pt product should be unnecessary. This research is to establish if chloride-free $\mathrm{Pt}$ catalysts could be prepared using complex of the type $\left(\mathrm{NH}_{4}\right)_{2} \mathrm{Pt}(\mathrm{ox})_{2} \cdot 2 \mathrm{H}_{2} \mathrm{O}$.

\section{EXPERIMENTAL AND METHOD}

Ammonium bisoxalatoplatinate(II) (NH4)2Pt(ox)2.2H2O was prepared using a modification of the method described by Schlutz et al., for $\mathrm{Co}_{0.83} \mathrm{Pt}(\mathrm{ox})_{2} \cdot 6 \mathrm{H}_{2} \mathrm{O} .{ }^{17} \mathrm{An}$ excess of $1 \mathrm{M}$ $\mathrm{HCl}$ was added to $\mathrm{Ag}_{2} \mathrm{Pt}(\mathrm{ox})_{2}(5 \mathrm{~g}, 0.008 \mathrm{~mol})$ suspended in $100 \mathrm{~mL}$ of water. The resulting $\mathrm{AgCl}$ precipitate, coagulated by heating the solution, was removed by filtration to yield a clear yellow solution of $\mathrm{H}_{2} \mathrm{Pt}(\mathrm{ox})_{2}$. $\left(\mathrm{NH}_{4}\right)_{2}$ (ox) (2 g, $0.016 \mathrm{~mol}$ ) dissolved in $20 \mathrm{~mL}$ of water was added to the filtrate and the resulting yellow solution was re-filtered and allowed to stand, in air, at room temperature for 2 weeks. The solution slowly turned blue and deposited yellow needle-shaped crystals of the desired product. These were collected and washed successively with cold water, alcohol and acetone and finally air dried.

The preparation of alumina supported (NH4)2Pt(ox)2.2H2O was achieved by dissolving
$\left(\mathrm{NH}_{4}\right)_{2} \mathrm{Pt}(\mathrm{ox})_{2} .2 \mathrm{H}_{2} \mathrm{O}(0.4964 \mathrm{~g}, 0.0013 \mathrm{~mol})$ in $25 \mathrm{~mL}$ of hot water containing a suspension of $\mathrm{Al}_{2} \mathrm{O}_{3}$ $(2.549 \mathrm{~g}, 0.025 \mathrm{~mol})$. The volume of the solution was then reduced to about $5 \mathrm{~mL}$ by heating rapidly and stirred solution at near boiling point. After cooling to room temperature, the yellow solid was collected and successively washed with cold water, alcohol and acetone and finally air dried. Samples were heat treated in a muffle furnace for four hours at $950^{\circ} \mathrm{C}$ and $1100^{\circ} \mathrm{C}$ for unsupported and supported samples, respectively.

Infrared (IR) spectra were recorded on a Biorad FTS-40 spectrophotometer between 400 to $4000 \mathrm{~cm}^{-1}$. Powder X-ray diffraction (XRD) patterns of the samples were collected using CuK $\alpha$ radiation $(\lambda=1.5405 \AA$ ) peaks, observed at $2 \theta$ range between $5^{\circ}$ to $90^{\circ}$ with step size of $0.01^{\circ}$ per second, and recorded on a Siemens D5000 diffractometer operating the DIFFRAC 500 software. Scanning electron micrographs (SEM) were collected using a JEOL JSM-6000F microscope, while ttransmission electron microscopy (TEM) studies were performed on a Phillips CM12 microscope. Energy dispersive analysis (EDA) were performed with an EDAX PV9900 system on a Phillips 505 scanning electron microscope. X-ray photoelectron spectra (XPS) were recorded on a Kratos XSAM 800 spectrometer.

\section{RESULTS AND DISCUSSIONS}

Untreated unsupported and alumina supported ( $\mathrm{NH} 4) 2 \mathrm{Pt}(\mathrm{ox}) 2.2 \mathrm{H} 2 \mathrm{O}$ have been synthesized, and characterized using some methods. Comparison of the infrared spectra of alumina, untreated unsupported and alumina supported $\left(\mathrm{NH}_{4}\right)_{2} \mathrm{Pt}(\mathrm{ox})_{2} \cdot 2 \mathrm{H}_{2} \mathrm{O}$, suggests that (NH4)2Pt(ox)2.2H2O can be deposited onto alumina without any decomposition. It is clear from the infrared spectra that the structure of the three materials is different to each other. The broad and strong bands at the region $2800-3700 \mathrm{~cm}^{-1}$ of infrared spectra of the $\left(\mathrm{NH}_{4}\right)_{2} \mathrm{Pt}(\mathrm{ox})_{2} \cdot 2 \mathrm{H}_{2} \mathrm{O}$ sample feature the characteristic of $\mathrm{NH}_{4}^{+}$group and water, belong to (NH4)2Pt(ox)2.2H2O complex (Fig. 1.), as described in smectite and illite, ${ }^{18} \mathrm{NH}^{4+}$ ion in zeolitic materials, ${ }^{19}$ and $\mathrm{NH}_{4}{ }^{+}$-smectite nanocomposites. ${ }^{20}$ 


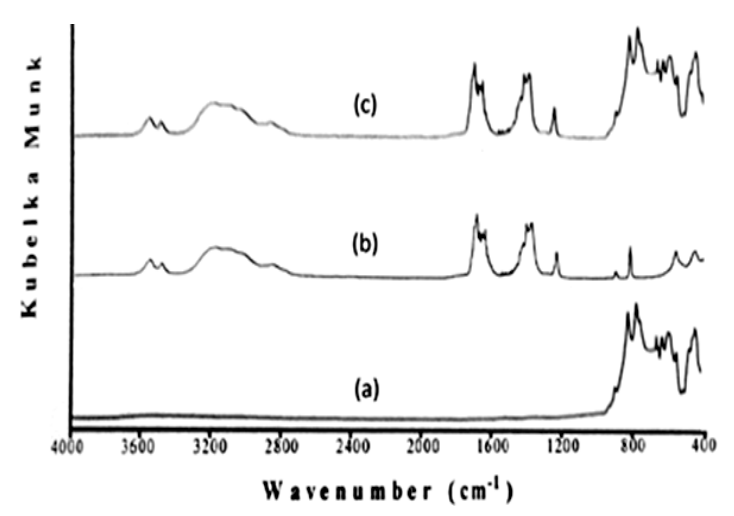

Fig. 1. The IR spectra of (a) alumina, (b) untreated unsupported, and (c) alumina supported $\left(\mathrm{NH}_{4}\right)_{2} \mathrm{Pt}(\mathrm{ox})_{2} \cdot 2 \mathrm{H}_{2} \mathrm{O}$

Scanning electron microscopy (SEM) was employed to study the morphology of the samples. Electron micrographs of $\left(\mathrm{NH}_{4}\right)_{2} \mathrm{Pt}(\mathrm{Ox})_{2} \cdot 2 \mathrm{H}_{2} \mathrm{O}$ is shown in Fig. 2.a. The complex forms needles being about $35 \mu \mathrm{m}$ long. In this case there is no evidence for any minority phases. Electron micrograph of alumina supported $\left(\mathrm{NH}_{4}\right)_{2} \mathrm{Pt}(\mathrm{ox})_{2} \cdot 2 \mathrm{H}_{2} \mathrm{O}$ is given in Fig. 2.b. The particle size of supported material is considerable smaller than the unsupported material. In this case well dispersed crystallites of oxalate complex is present on the surface the alumina particles. Chloride was not observed in the EDA of the sample studied (Figure 2.b).

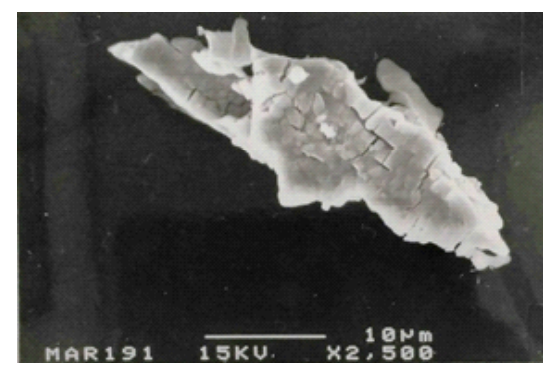

(a)

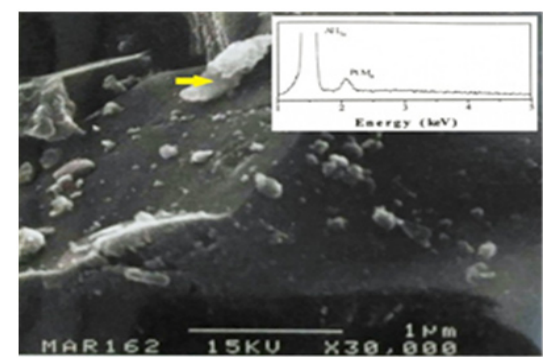

(b)

Fig. 2. Electron micrographs of (a) unsupported, (b) and alumina supported $\left(\mathrm{NH}_{4}\right)_{2} \mathrm{Pt}(\mathrm{ox})_{2} \cdot 2 \mathrm{H}_{2} \mathrm{O}$. An arrow points toward $\left(\mathrm{NH}_{4}\right)_{2} \mathrm{Pt}(\mathrm{Ox})_{2} \cdot 2 \mathrm{H}_{2} \mathrm{O}$ on the surface of alumina. The EDA spectra (b) indicates the presence of the main metals i.e. Al and Pt in the alumina supported $\left(\mathrm{NH}_{4}\right)_{2} \mathrm{Pt}(\mathrm{Ox})_{2} \cdot 2 \mathrm{H}_{2} \mathrm{O}$ sample
The XRD measurement confirms that the structure of the $\mathrm{NH}_{4}^{+}$salts of $\mathrm{Pt}(\mathrm{ox})_{2}{ }^{2-}$ is retained when it is deposited onto alumina (Fig. 3 ). The diffraction pattern of the complex did not show any lines, except these due to alumina. There is noticeable changes in the relative intensities of the Bragg reflections in the pattern of $\left(\mathrm{NH}_{4}\right)_{2} \mathrm{Pt}(\mathrm{Ox})_{2} \cdot 2 \mathrm{H}_{2} \mathrm{O}$, however this is believed to be a result preferential growth of the complex on the support.

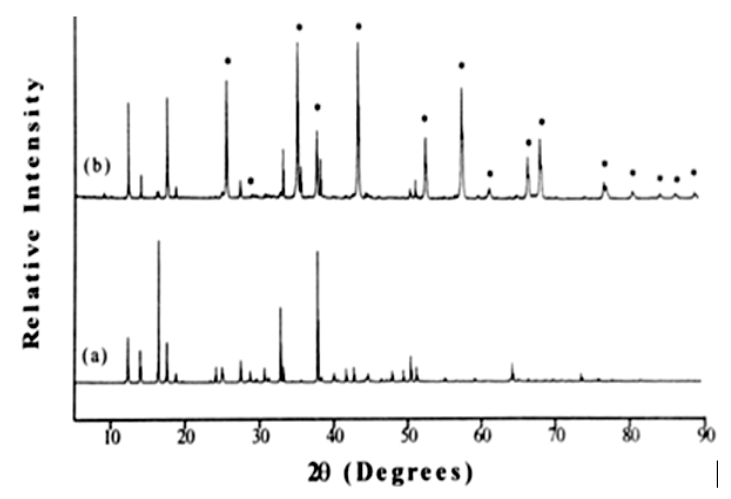

Fig. 3. XRD patterns of (a) unsupported and (b) alumina supported $\left(\mathrm{NH}_{4}\right)_{2} \mathrm{Pt}(\mathrm{ox})_{2} \cdot 2 \mathrm{H}_{2} \mathrm{O}$. Lines marked (*) are due to alumina

The XRD patterns of the decomposition products of alumina supported $\left(\mathrm{NH}_{4}\right)_{2} \mathrm{Pt}(\mathrm{ox})_{2} \cdot 2 \mathrm{H}_{2} \mathrm{O}$ formed at different temperatures are given in Fig. 4. Heat treatment at $400^{\circ} \mathrm{C}$ produces Pt metal. Heating the sample at temperatures between $500^{\circ} \mathrm{C}$ to $1100^{\circ} \mathrm{C}$ results in crystallization of $\mathrm{Pt}$. The $\mathrm{Pt}$ is stable even after heating to $1100^{\circ} \mathrm{C}$. Unfortunately, the limitation of heat treatment unsupported sample causes the XRD pattern unable to collect.

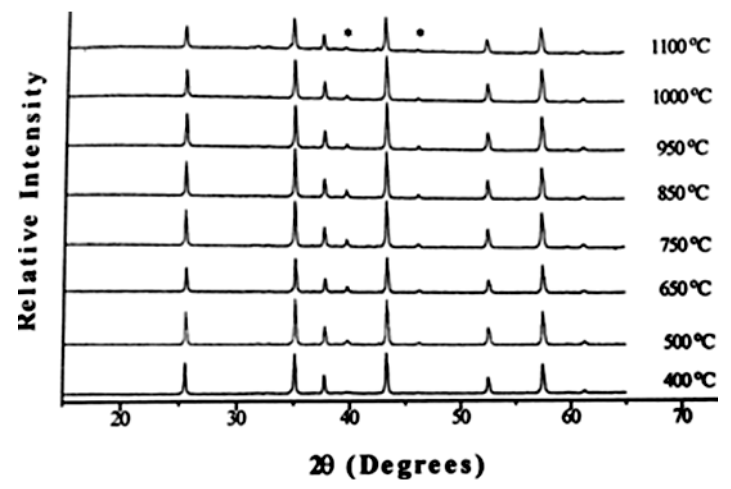

Fig. 4. XRD patterns of heat treatment products of alumina supported $\left(\mathrm{NH}_{4}\right)_{2} \mathrm{Pt}(\mathrm{ox})_{2} \cdot 2 \mathrm{H}_{2} \mathrm{O}$. Lines marked $\left(^{\star}\right)$ are due to $\mathrm{Pt}^{21}$

SEM and EDA were also employed to characterized heat treated unsupported and alumina supported $\left(\mathrm{NH}_{4}\right)_{2} \mathrm{Pt}(\mathrm{Ox})_{2} \cdot 2 \mathrm{H}_{2} \mathrm{O}$. The SEM and EDA of the samples are shown in Fig. 5 and 6, respectively. 
The electron micrographs of $\left(\mathrm{NH}_{4}\right)_{2} \mathrm{Pt}(\mathrm{ox})_{2} \cdot 2 \mathrm{H}_{2} \mathrm{O}$ heated at $400^{\circ} \mathrm{C}$ produces spherical crystallites sizes about $0.1 \mu \mathrm{m}$ diameter which then collapsed after further heating at $550^{\circ} \mathrm{C}$ forming rounded particles sized about $30 \mathrm{~nm}$ diameter. Upon additional heating of the samples at $650^{\circ} \mathrm{C}$, the particle grew, forming a smooth honey-comb like structure. EDA on various heat treated samples shows that the only element present was Pt. ${ }^{21}$

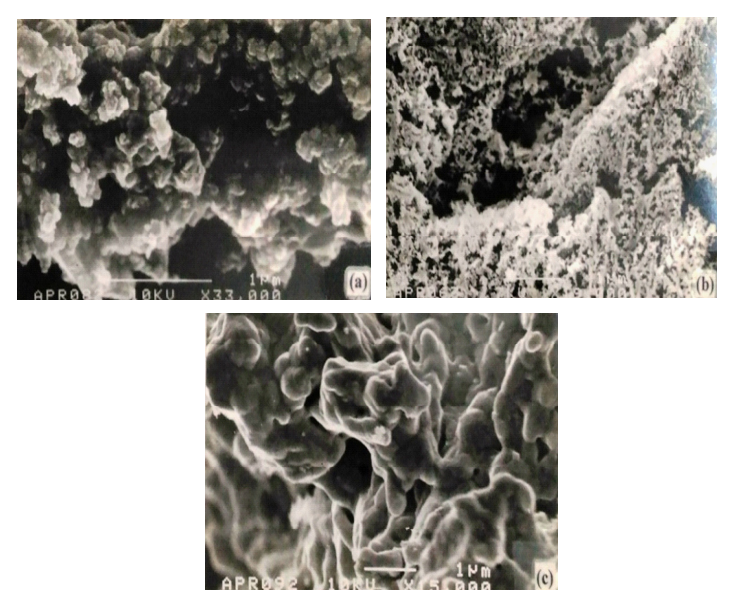

Fig. 5. Electron micrographs of unsupported $\left(\mathrm{NH}_{4}\right)_{2} \mathrm{Pt}(\mathrm{ox})_{2}$. $2 \mathrm{H}_{2} \mathrm{O}$ after heating at $400^{\circ} \mathrm{C}(\mathrm{a}), 550^{\circ} \mathrm{C}(\mathrm{b})$, and $650^{\circ} \mathrm{C}$ (c) for 4 hours

SEM and EDA spectra of heat treated alumina supported $\left(\mathrm{NH}_{4}\right)_{2} \mathrm{Pt}(\mathrm{Ox})_{2} \cdot 2 \mathrm{H}_{2} \mathrm{O}$ are shown in Fig. 7 and 8. The electron micrographs of the material heated from 400 to $700^{\circ} \mathrm{C}$ showed a range of poorly formed crystallites to be present, whilst heating at higher temperature produces more crystalline materials of various size from 50 to $300 \mathrm{~nm}$ on the surface of alumina support. In comparison to the unsupported materials, it is apparent that the net-like particles did not persist on the surface of support. This is presumably has implications for sintering or reactions of the particles with the surface of support.

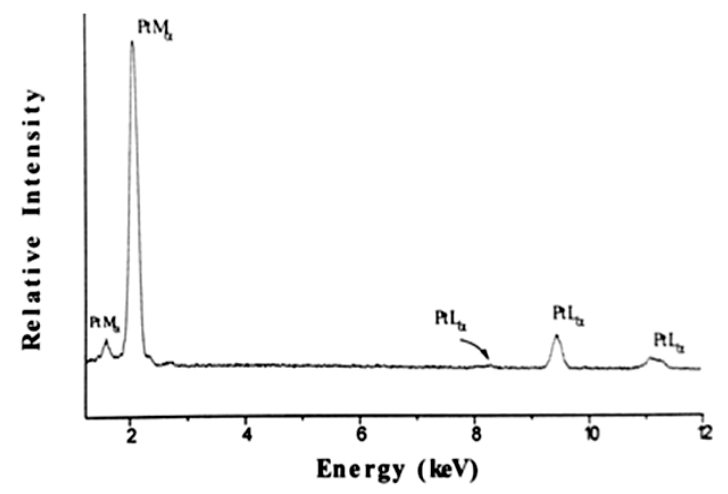

Fig. 6. EDA spectra of unsupported $\left(\mathrm{NH}_{4}\right)_{2} \mathrm{Pt}(\mathrm{Ox})_{2} \cdot 2 \mathrm{H}_{2} \mathrm{O}$ after heating at $550^{\circ} \mathrm{C}$ for 4 hours

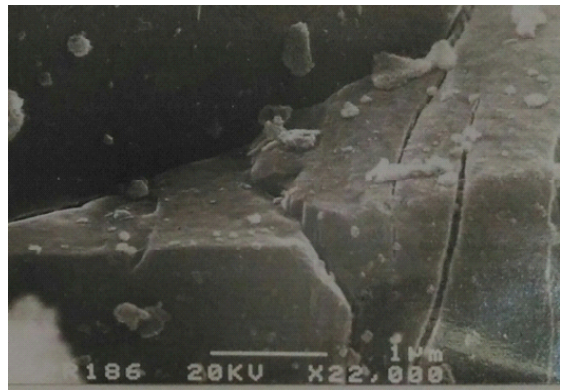

Fig. 7. Electron micrographs of alumina supported $\left(\mathrm{NH}_{4}\right)_{2} \mathrm{Pt}(\mathrm{ox})_{2} \cdot 2 \mathrm{H}_{2} \mathrm{O}$ after heating at $4000 \mathrm{C}$ for 4 hours

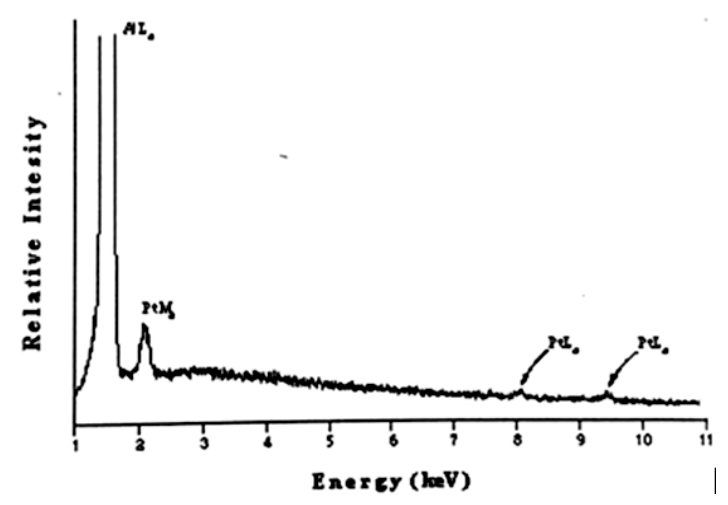

Fig. 8. EDA spectra of alumina supported $\left(\mathrm{NH}_{4}\right)_{2} \mathrm{Pt}(\mathrm{ox})_{2} \cdot 2 \mathrm{H}_{2} \mathrm{O}$ after heating at $950^{\circ} \mathrm{C}$ for 4 hours

TEM was used in order to characterize any small particles that may form on the surface of heat treated alumina supported materials. For the Pt complex a range of particle sizes were observed and the precise size of the crystallites depended on the heating conditions. For example, the heat treating the alumina supported platinum complex at $600^{\circ} \mathrm{C}$ produces particles with size ranging from 15 to $37 \mathrm{~nm}$, which is somewhat bigger size than that found by Ivanova, ${ }^{21}$ distributed over the alumina support (Fig. 9), as confirmed by EDA spectra (Fig. 10) and XRD measurement (Figure 4).

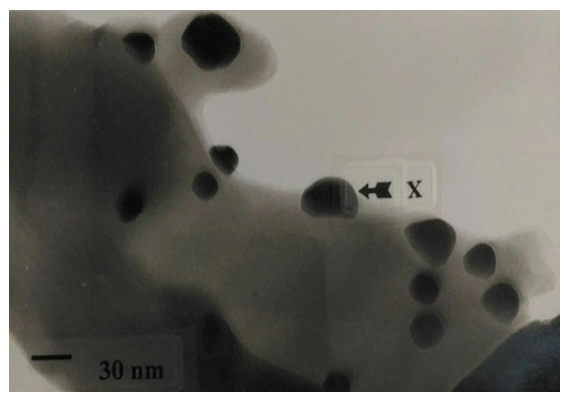

Fig. 9. TEM of heat treated alumina supported $\left(\mathrm{NH}_{4}\right)_{2} \mathrm{Pt}(\mathrm{ox})_{2} \cdot 2 \mathrm{H}_{2} \mathrm{O}$ at $600^{\circ} \mathrm{C}$. 


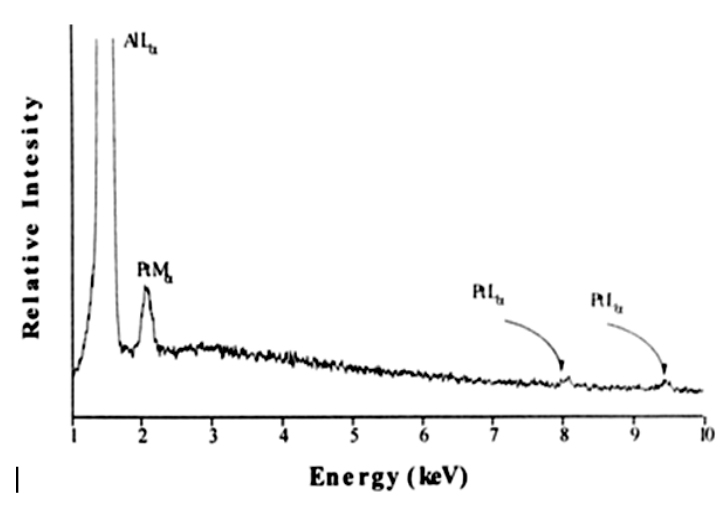

Fig. 10. EDA spectra of a particle $X$ on the alumina support

The surface composition on the heat treated alumina supported sample was studied by XPS. The survey spectra on the alumina supported sample after heating at $400^{\circ} \mathrm{C}$ for $4 \mathrm{~h}$ was collected (Fig. 11). The spectra are dominated by strong Al and O signals from alumina support; all other lines observed are as expected. No lines due to $\mathrm{Cl}$ were observed.

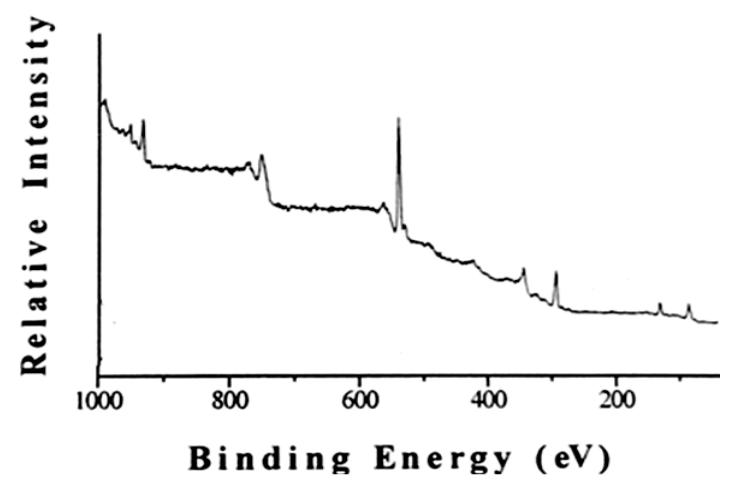

Fig. 11. XPS survey spectra of alumina supported $\left(\mathrm{NH}_{4}\right)_{2} \mathrm{Pt}(\mathrm{Ox})_{2} \cdot 2 \mathrm{H}_{2} \mathrm{O}$ after heating at $400^{\circ} \mathrm{C}$ and water washing. The $\mathrm{BE}$ value on the graphs have not been corrected for charging effect
Partial overlap of the Pt $4 f$ and $\mathrm{Al} 2 p$ lines complicates the analysis of the Pt $4 f$ spectra (Fig. 12). Peak fitting analysis suggest a single Pt species is present with $\mathrm{Pt} 4 f_{7 / 2} \mathrm{BE}$ of $70.9 \mathrm{eV}$ indicating $\mathrm{Pt}(0) .{ }^{22}$ The spectra provided no evidences for the presence of any Pt oxides.

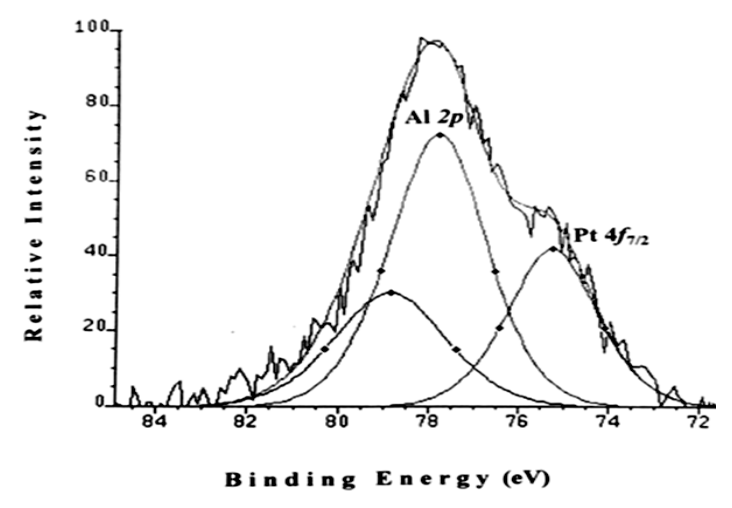

Fig. 12. Pt $4 f$ spectra of alumina supported $\left(\mathrm{NH}_{4}\right)_{2} \mathrm{Pt}(\mathrm{ox})_{2} \cdot 2 \mathrm{H}_{2} \mathrm{O}$ after heated at $950^{\circ} \mathrm{C}$. The $\mathrm{BE}$ value on the graphs have not been corrected for charging effects of $2.8 \mathrm{eV}$

\section{CONCLUSION}

A series of IR, XRD, SEM, TEM, EDA and XPS studies showed that $\left(\mathrm{NH}_{4}\right)_{2} \mathrm{Pt}(\mathrm{ox})_{2} \cdot 2 \mathrm{H}_{2} \mathrm{O}$ can be prepared and can be used to prepare unsupported and alumina supported $\mathrm{Pt}$ free of chloride impurities.

\section{ACKNOWLEGEMENT}

I am thankful to Prof. B. J. Kennedy (Unversity of Sydney, Australia) who provided expertise that greatly assisted the research, and all of the interpretations provided in this manuscript.

\section{REFERENCES}

1. Thurier, C.; Doppelt, P., Coordination Chemistry Reviews., 2008, 252, 155-169.

2. Lashdaf, M.; Lahtinen, J.; Lindblad, M.; Venäläinen, T.; Krause, A.O.I., Appl. Catal. A Gen., 2004, 276, 129-137.

3. Zhao, J.; Gou, S.; Liu, F.; Sun, Y.; Gao, C., Inorg. Chem., 2013, 52, 8163-8170.

4. Gavrilovic, L.; Brandin, J.; Holmen, A.; Venvik, H.J.; Myrstad, R.; Blekkan, E.A., Ind. Eng. Chem. Res., 2018, 57, 1935-1942.

5. Pendyala, V.R.R.; Jacobs, G.; Ma, W.; Sparks, D.E.; Shafer, W.D.; Khalid, S.; Xiao, Q.; Hu,
Y.Davis, B.H., Catal. Letters., 2016, 146, 1858-1866.

6. Knapp, S.M.M.; Knapp, S.M.M.; Sherbow, T.J.; Ahmed, T.J.; Thiel, I.; Zakharov, L.N.; Juliette, J.J.; Tyler, D.R., J. Inorg. Organomet. Polym. Mater., 2014, 24, 145-156.

7. Wu, X.; Yu, W.; Si, Z.; Weng, D., Front. Environ. Sci. Eng., 2013, 7, 420-427.

8. Oh, H.-S.; Yang, J.H.; Costello, C.K; Wang, Y.M.; Bare, S.R.; Kung, H.H.; Kung, M.C., J. Catal., 2002, 210, 375-386.

9. Štarha, P.; Trávnícek, Z.; Popa, I., J. Inorg. Biochem., 2010, 104, 639-647. 
10. Al-Jibori, S.A.; Barbooti, M.M., Al-Jibori, M.H.S.; Aziz, B.K., J. Mater. Environ. Sci., 2017, 8, 1365-1374.

11. Rodríguez, D.; Sánchez, J.; Arteaga, G., Journal of Molecular Catalysis A: Chemical., 2005, 228, 309-317.

12. Zhang, Y.; Zhao, C.Y.; Liang, H.; Liu, Y., Catal. Letters., 2009, 127, 3-4.

13. Batista, S.G.; Afonso, J.C., J. Hazard. Mater., 2010, 184, 717-723.

14. Jackson, S. D.; Matheson, I.M.; Naeye, M.-L.; Stair, P.C.; Sullivan, V.S.; Watson, S.R.; Webb, G., Stud. Surf. Sci. Catal., 2000, 130, 2213-2218.

15. Yamamoto, C.; Nishikawa, H.; Nihei, M.; Shiga, T.; Hedo, M.; Uwatoko, Y.; Sawa, H.; Kitagawa, H.; Taguchi, Y.; Iwasa, Y.; Oshio, H., Inorg. Chem., 2006, 45, 10270-10276.
16. Broach, R.W.; Kirchner, R.M., Microporous Mesoporous Mater., 2011, 143, 398-400.

17. Schultz, A.J.; Underhill, A.E.; Williams, J.M., Inorg. Chem., 1978, 17, 1313-1315.

18. Pironon, J.; Pelletier, M.; de Donato, P.; Mosser-Ruck, R., Clay Miner., 2003, 38, 201-211.

19. Barbera, K.; Lanzafame, P.; Perathoner, S.; Centi, G.; Migliori, M.; Aloise, A.; Giordano, G., New J. Chem., 2016, 40, 4300-4306.

20. Bobos, I., Am. Mineral., 2012, 97, 962-982.

21. Ivanova, A.S.; Slavinskaya, E.M.; Gulyaev, R.V.; Zaikovskii, V.I.; Stonkus, O.A.; Danilova, I.G.; Plyasova, L.M.; Polukhina, I.A.; Boronin, A.I., Appl. Catal. B Environ., 2010, 97, 57-71.

22. Chastain, J., Handbook of X-Ray Photoelectron Spectroscopy, Perkin-Elmeer Corporation., 1992. 